J. Dairy Sci. 99:5707-5718

http://dx.doi.org/10.3168/jds.2015-10782

(C) American Dairy Science Association ${ }^{\circledR}, 2016$.

\title{
Cabergoline inhibits prolactin secretion and accelerates involution in dairy cows after dry-off
}

\author{
M. Boutinaud, ${ }^{*} \dagger^{1}$ N. Isaka, $\ddagger$ V. Lollivier, ${ }^{\star} \dagger \S$ F. Dessauge,${ }^{*} \dagger$ E. Gandemer, ${ }^{*} \dagger$ P. Lamberton, ${ }^{*} \dagger$ \\ A. I. De Prado Taranilla, $\neq$ A. Deflandre, $\ddagger$ and L. M. Sordillo\# \\ *INRA, UMR1348 Pegase, F-35590 Saint-Gilles, France \\ †Agrocampus-Ouest, UMR1348 Pegase, F-35000 Rennes, France \\ ‡Ceva Santé Animale, F-33500 Libourne, France \\ §Université Européenne de Bretagne, F-35000 Rennes, France \\ \#Department of Large Animal Clinical Sciences, College of Veterinary Medicine, Michigan State University, East Lansing 48824
}

\begin{abstract}
Dairy cattle require a dry period between successive lactations to ensure optimal milk production. Because prolactin (PRL) is necessary for the initiation and maintenance of milk production, strategies that can inhibit PRL secretion might hasten the involution process. The objective of this study was to determine the effect of the PRL release inhibitor cabergoline on markers of mammary gland involution during the early dry period. To assess the effect of cabergoline treatment on mammary gland involution, 14 Holstein dairy cows in late lactation were treated with either a single i.m. administration of $5.6 \mathrm{mg}$ of cabergoline (Velactis, Ceva Santé Animale, Libourne, France, $\mathrm{n}=7)$ or placebo $(\mathrm{n}=7)$ at the time of dry-off. Blood samples and mammary secretion samples were collected 6 d before dry-off and again $1,2,3,4,8$, and $14 \mathrm{~d}$ following the abrupt cessation of lactation. Blood samples were used to determine plasma PRL concentrations. Mammary secretion samples were used to determine somatic cell count, milk fat, lactose, true protein content, and concentrations of $\alpha$-lactalbumin, lactoferrin, and citrate. Following the cessation of lactation, changes in mammary secretion composition indicated diminished milk synthesis, including reduced concentrations of $\alpha$-lactalbumin, citrate, and lactose. In contrast, milk somatic cell count, percent total protein, percent fat content, and lactoferrin concentrations significantly increased as involution progressed. Cabergoline treatment decreased the plasma PRL concentrations during the first week of dry-off, compared with the control treatment. No significant differences in citrate, $\alpha$-lactalbumin, or protein content were observed between treatment groups. The most dramatic changes in secretion composition
\end{abstract}

Received December 18, 2015.

Accepted March 30, 2016.

${ }^{1}$ Corresponding author: marion.boutinaud@rennes.inra.fr as a consequence of cabergoline treatment occurred during the first week of the dry period, when lactose concentrations and the citrate:lactoferrin molar ratio were lower and lactoferrin concentrations higher than in the control cows. Cabergoline treatment also tended to increase fat content and somatic cell count more rapidly following dry-off compared with the control group. These changes in mammary secretion composition following the abrupt cessation of lactation indicate that cabergoline treatment facilitated dry-off and effectively accelerated mammary gland involution.

Key words: mammary gland, dairy cow, drying-off, prolactin, involution

\section{INTRODUCTION}

The dry period is an important phase of a dairy cow's lactation cycle and is routinely implemented on most dairy farms. Previous studies clearly document the importance of a dry period lasting 40 to $60 \mathrm{~d}$ for optimal milk production (Collier et al., 2012). The overall benefits derived from the dry period are thought to be a consequence of adequate mammary gland secretory cell turnover and differentiation between consecutive lactations (Capuco et al., 2003). Although the dry period is essential from the standpoint of lactation physiology, the abrupt cessation of lactation has become problematic with the modern dairy cow, which may produce 25 to $30 \mathrm{~kg} / \mathrm{d}$ of milk at the time of dry-off (Stefanon et al., 2002). Researchers have shown that high-producing dairy cows are more susceptible to new intramammary infection during the early dry period (Rajala-Schultz et al., 2005). This susceptibility can be related to excessive accumulation of milk at the time of dry-off, which may lead to milk leakages (Zobel et al., 2015) and reduce the functional capabilities of mammary leukocyte populations (Oliver and Sordillo, 1989). Fully involuted mammary glands are more resistant to new bacterial infections, and the mammary glands of cows entering 
the dry period with lower milk production involute at a faster rate than those of high-producing dairy cows (Bushe and Oliver 1987; Oliver and Sordillo, 1989). Moreover, excessive mammary gland engorgement at the time of dry-off in high-producing dairy cows may be a significant source of discomfort and pain (O'Driscoll et al., 2011; Silanikove, 2014). The dairy industry needs practical management strategies to effectively dry off high-producing dairy cows at the end of their lactations.

Upon abrupt cessation of lactation, the bovine mammary gland undergoes complex molecular and cellular changes that are needed to ensure optimal milk production in the subsequent lactation (Capuco and Akers, 1999; Kuhn et al., 2006; Watters et al., 2008). Cessation of milk removal initiates the involution process, which includes udder engorgement and increased intramammary pressure (Hurley, 1989). Changes in mammary tissue morphology and function begin at dry-off; some changes are rapid, whereas others are progressive, such as a decrease in secretory cell activity, an increase in epithelial cell turnover, and the infiltration of leukocytes into mammary tissue spaces to remove cellular debris (Hurley, 1989; Oliver and Sordillo, 1989). Changes in the composition of mammary secretions during the onset of involution reflect a rapid decline in mammary epithelial cell function; these changes include a reduction in major milk constituents, such as lactose and casein. In contrast, lacteal concentrations of factors associated with mammary gland defenses, such as leukocytes and the bacteriostatic whey protein lactoferrin, progressively increase (Hurley, 1989; Oliver and Sordillo, 1989; Kutila et al., 2003). The most rapid changes in bovine mammary tissue morphology and function occur within the first week of the dry period, whereas the complete transition from a lactating to nonlactating state is thought to be completed 3 to $4 \mathrm{wk}$ following the abrupt cessation of lactation (Holst et al., 1987; Hurley, 1989).

Milk stasis and distension of mammary secretory tissues are thought to contribute to the involution process through local chemical feedback by milk constituents, formation of other inhibitor factors in secretions, and mechanical stress to alveolar cells that can lead to the loss of secretory function (Collier et al., 2012). However, the maintenance of lactation is also under endocrine control by galactopoietic hormones such as prolactin (PRL; Lacasse et al., 2016). Prolactin is mainly produced by the lactotrophs of the anterior pituitary under the negative control exerted by dopamine (Ingram et al., 1986). A surge of PRL is released into plasma not only at parturition, but also at each milking (Koprowski and Tucker, 1973). Recent evidence supports this galactopoietic role for PRL, as this hormone is essential for maintaining lactation and its suppression strongly inhibits lactation in ruminants (Lacasse et al., 2016). The ability of dopamine agonists to inhibit PRL secretion is a factor in suppressing unwanted lactation in women and female dogs (de Groot et al., 1998). In cows, the inhibition of PRL secretion by the pituitary gland after daily injections of quinagolide, a dopamine agonist, was also shown to reduce milk yield during established lactation (Lacasse et al., 2011; Lollivier et al., 2015). This decrease in milk yield was associated with lower levels of milk protein mRNA, in conjunction with reduced mammary epithelial cell survival and proliferation (Boutinaud et al., 2012). In contrast, PRL injections restored mammary epithelial cell proliferation and survival (Lollivier et al., 2015). In addition, injections of quinagolide at dry-off were shown to accelerate mammary gland involution (Ollier et al., 2013). Thus, inhibiting PRL secretion may be one approach to facilitating mammary gland involution in dairy cattle at dry-off.

Another powerful dopamine agonist, cabergoline, is an ergot derivative that has a high affinity for D2 dopamine receptors. Cabergoline is used in women to treat hyperprolactinemia (Crosignani, 2006) and suppress lactation (de Groot et al., 1998; Gobello, 2006). A recent study reported that a single injection of cabergoline is able to reduce plasma PRL concentrations in dairy cows at dry-off (Bach et al., 2015). In addition, the cabergoline treatment at dry-off also reduced udder engorgement (measured by a digital algometer), decreased the incidence of milk leakage, and improved lying time the day following dry-off (Bach et al., 2015). To date, however, how cabergoline acts on milk synthesis during the early stages of involution is unknown. Thus, the objective of this study was to determine whether treating cows with cabergoline at the time of dry-off could accelerate mammary gland involution during the early dry period.

\section{MATERIALS AND METHODS}

\section{Animals and Experimental Design}

All the procedures applied to animals were approved by the Animal Care Committee of the French Ministry of Agriculture and were in accordance with French regulations (Decree No. 2001-464, May 26, 2001). The study was designed and performed in compliance with European VICH Topic GL9 (GCP): Good Clinical Practice.

Fourteen multiparous Holstein cows $(644 \pm 16.8 \mathrm{~kg}$ of BW) with $323 \pm 21.6$ DIM producing $16.8 \pm 0.91$ 
$\mathrm{kg}$ of milk at dry-off were randomly assigned to treatment groups. The cows were separated into 2 treatment groups that were balanced by milk production, age, BW, lactation rank, pregnancy status, DIM, and the 3 last SCC, measured at $\mathrm{d}-13,-10$, and -7 (Table 1) relative to dry-off. For milk production, the average milk yield in the second-last week before drying-off (i.e., mean from d -14 to -7 ) was used. The cows were housed at the INRA Méjusseaume experimental dairy farm (UMR1348 IEPL, Le Rheu, France) and managed in individual tie stalls. Before drying-off, the cows were milked twice daily. Milk production at each milking was individually recorded during the trial. All cows were treated with an intramammary antibiotic (Cobactan, Intervet, Beaucouzé, France) after the last milking. The cows were equipped with a silastic permanent catheter (Silclear medical-grade silicone tubing, i.d. $1.02 \mathrm{~mm}$, o.d. $2.16 \mathrm{~mm}$; Degania Silicone, Degania Bet, Israel), which was surgically inserted in the jugular vein the day before the first blood sampling and remained there for the duration of the study.

The treatment consisted of a single aseptic 5-mL i.m. administration in the neck of a solution containing 5.6 mg of cabergoline (CAB; Velactis, Ceva Santé Animale, Libourne, France) or an i.m. injection of $5 \mathrm{~mL}$ of the same excipient used in CAB as a placebo (CTRL) within $4 \mathrm{~h}$ after the last milking before drying-off (d 0 ). The cows were fed according to INRA guidelines. The cows were fed ad libitum with a late lactation diet containing (on a DM basis) $83.5 \%$ corn silage, $7 \%$ soybean meal, $8.5 \%$ non-mineral supplement, and $1 \%$ mineral supplement. After drying-off, all cows were fed with a dry-period diet based on dry hay for the first $10 \mathrm{~d}$ of the dry period. Starting at d 11 in the dry period, a diet containing (on a DM basis) $50 \%$ corn silage, $40 \%$ dry hay, $9 \%$ soybean meal, and $1 \%$ mineral supplement was provided. Feed intake was individually recorded each day during the trial.

\section{Blood Sample Collection and Analyses}

Blood samples were collected with Monovette syringes coated with sodium heparin (Sarstedt, Nümbrecht, Germany) before and during the morning milking at $\mathrm{d}-7$ to determine PRL release at milking. The blood samples were taken $-10,-2,2,5,10,15$, and $25 \mathrm{~min}$ relative to milking-unit attachment. Blood was also collected before and after the collection of mammary secretion samples at $\mathrm{d}-6,1,2,3,4,8$, and 14 . Plasma was separated by centrifugation at $4^{\circ} \mathrm{C}$ and $3,000 \times g$ for 15 min and then stored at $-20^{\circ} \mathrm{C}$ for subsequent analysis. Plasma PRL concentrations were measured using an indirect competitive ELISA with a rabbit-anti-prolactin antibody (Kollmann et al., 2008). Intraassay variability was $<2 \%$, and interassay variability was $<12 \%$. The sensitivity of the assay was $0.7 \mathrm{ng} / \mathrm{mL}$. At $\mathrm{d}-7$, basal PRL concentration was determined as the PRL concentration in plasma at -2 min relative to milking-unit attachment; PRL peak concentration was determined as the maximum PRL concentration in plasma in the first

Table 1. Baseline production parameters and milking-induced prolactin release in dairy cows assigned to the cabergoline $(\mathrm{CAB})$ or vehicle $(\mathrm{CTRL})$ treatment groups before dry-off ${ }^{1}$

\begin{tabular}{lccc}
\hline Item & CAB & CRTL & $P$-value \\
\hline Age (d) & $1,490 \pm 138$ & $1,400 \pm 137$ & 0.67 \\
Lactation rank & $1.9 \pm 0.34$ & $1.9 \pm 0.34$ & 1.00 \\
DIM (d) & $346 \pm 41.6$ & $300 \pm 10.3$ & 0.30 \\
BW (kg) & $646 \pm 20.8$ & $642 \pm 28.1$ & 0.92 \\
Days in pregnancy (d) & $214 \pm 2.8$ & $213 \pm 4.7$ & 0.84 \\
SCC mean (cells/mL) & $93,800 \pm 16,400$ & $102,300 \pm 31,200$ & 0.81 \\
Mean milk production ${ }^{2}(\mathrm{~kg})$ & $15.3 \pm 1.61$ & $8,240 \pm 1.46$ & 0.89 \\
Milk production, 305 d (kg) & $9,910 \pm 2,290$ & $16.9 \pm 1.20$ & 0.89 \\
Mean milk production $^{3}(\mathrm{~kg})$ & $16.7 \pm 1.48$ & $3,800 \pm 980$ & 0.89 \\
Prolactin & & $24.7 \pm 2.01$ & 0.29 \\
AUC (ng/25 min) & $7,190 \pm 2,870$ & $8.1 \pm 1.74$ & 0.74 \\
Peak (ng/mL) & $26.9 \pm 6.2$ & $16.6 \pm 1.08$ & 0.51 \\
Delta (ng/mL) & $11.7 \pm 5.06$ & 0.45 \\
Basal (ng/mL) & $15.2 \pm 1.44$ & & \\
\hline
\end{tabular}

${ }^{1}$ Data are presented as mean \pm SEM. Student's $t$-test was used to compare CAB and CTRL data.

${ }^{2}$ Daily mean milk production between $\mathrm{d}-2$ and $\mathrm{d}-1$ relative to drying-off.

${ }^{3}$ Daily mean milk production between $\mathrm{d}-14$ and $\mathrm{d}-7$ relative to drying-off.

${ }^{4} \mathrm{AUC}=$ area under the curve representing prolactin concentration in plasma during the first 25 min following milking-unit attachment; peak = maximum prolactin concentration in plasma during the first 25 min following milking-unit attachment; delta $=$ difference between peak and basal values; basal = prolactin concentration in plasma before milking-unit attachment ( $-2 \mathrm{~min})$. 
25 min following milking-unit attachment; and delta PRL was determined as the difference between the peak and basal values. The amounts of PRL released into the blood at milking were calculated by determining the area under the curve representing PRL concentration in the first 25 min following milking-unit attachment (Table 1).

\section{Mammary Secretion Sample Collection}

Mammary secretion samples were collected in the morning from both front mammary quarters of each cow using a sterilized stainless steel intraductal cannula $(8 \mathrm{~cm}$, Luer Lock, Clinique Vétérinaire des Faluns, Saint-Grégoire, France) once during lactation (d -6) and again at d 1, 2, 3, 4, 8, and 14 after drying-off. A sterile cannula connected to a plastic tube was gently introduced into the teat sphincter of both front quarters of each cow to collect mammary secretions into a flask. A total of $290 \mathrm{~mL}$ of mammary secretions was collected from each cow; half of the volume came from each front quarter.

Mammary secretion samples were used, in part, for determination of SCC, milk fat, true protein, and lactose content by a commercial laboratory (Lillab, Châteaugiron, France) using an infrared method. Skim milk preparations were obtained by centrifugation and stored frozen at $-20^{\circ} \mathrm{C}$ until analyzed for citrate, $\alpha$-LA, and lactoferrin concentrations. For citrate determination, $7 \mathrm{~mL}$ of fresh milk was defatted by $45 \mathrm{~min}$ of centrifugation at $50,000 \times g$ at $1^{\circ} \mathrm{C}$. The aqueous phase was used for measuring citrate concentration on a multiparameter analyzer (KONE Instruments Corp., Espoo, Finland) using a commercial kit (Citric Acid Test Kit, Roche Diagnostics, Meylan, France). For $\alpha$-LA and lactoferrin determination, mammary secretion samples were skimmed by centrifugation at $1,500 \times g$ for $15 \mathrm{~min}$ at $4^{\circ} \mathrm{C}$. Radial immune diffusion (RID) analyses for $\alpha-\mathrm{LA}$ and lactoferrin were performed with specific RID kits (IDBiotech, Issoire, France). Briefly, the skim milk samples were diluted at 1:100 for the $\alpha$-LA assay and 1:9 for the lactoferrin assay in SRID buffer (IDBiotech) and loaded ( $15 \mu \mathrm{L}$ per well) onto RID plates containing agar gel with anti- $\alpha$-lactalbumin or anti-lactoferrin antiserum. The RID plates were incubated in a humidified atmosphere at $37^{\circ} \mathrm{C}$ for $16 \mathrm{~h}(\alpha-\mathrm{LA}$ assay) or $48 \mathrm{~h}$ (lactoferrin assay). The plates were then incubated with $2 \%$ acetic acid for 2 min and rinsed with water. Images were captured with the IDRing Viewer (IDBiotech), and the precipitation rings were analyzed using IDRing Meter software (IDBiotech). Intraassay variability was $<2 \%$, and interassay variability was $<6 \%$. Sensitivity values were 11.2 and $3.4 \mu \mathrm{g} / \mathrm{mL}$ for the $\alpha-\mathrm{LA}$ and lactoferrin assays, respectively.

\section{Statistical Analyses}

Prerequisites for running each test were checked and data normality was tested with the Shapiro-Wilk test. Any SCC data not normally distributed were transformed to decimal logarithms for statistical analysis. Data were analyzed by ANOVA using the MIXED procedure of the SAS software program (SAS Institute, Cary, NC) with the REPEATED statement. Day was used as a repeated effect, and cow (treatment) was used as the subject. The corresponding mixed model was as follows:

$$
Y_{i j k}=\mu+\alpha_{i}+\beta_{j}+\alpha_{i} \beta_{j}+\gamma_{k}+\delta_{i j}+\varepsilon_{i j k},
$$

where $Y_{i j k}$ is the concerned criterion for cow $k$ given treatment $i$ at day $j ; \mu$ is the overall mean of the concerned criterion; $\alpha_{i}$ is the fixed effect of the treatment $i$ $=\mathrm{CAB} ; \beta_{j}$ is the fixed effect at day $j(j=\mathrm{d} 1,2,3,4$, 8 , and 14$) ; \alpha_{i} \beta_{j}$ is the interaction between the $i$ th treatment and $j$ th day; $\gamma_{k}$ is the effect of the $k$ th cow within the given treatment; $\delta_{i j}$ is the effect of period (batch 1 or 2) (kept in the final model only if significant); and $\varepsilon_{i j k}$ is the residual error, assumed to be randomly distributed.

For all variables, the baseline obtained during the pretreatment period $(\mathrm{d}-6)$ was used as a covariate. The interaction between baseline and treatment was tested and kept in the model if significant. The effect of $\mathrm{CAB}$ treatment was evaluated with the slice option on the interaction term in the LSMEANS statement using the Tukey correction for multiple comparisons. The data from the observations before drying-off (the baseline) were tested for differences between the 2 groups of animals (CAB and CRTL) using Student's $t$-test. Assumption of equal variances was tested using the folded F-test; in cases of rejection of homogeneity the Satterthwaite correction was applied. Differences were considered statistically significant when $P \leq 0.05$, and trends were discussed at $0.05<P \leq 0.10$.

\section{RESULTS}

\section{Prolactin Concentration}

During the pretreatment period, we evaluated the baseline PRL parameters according to 2 measurements: the amount of PRL released at milking, determined using kinetic blood sample collection; and the basal PRL concentration in plasma (before milking). During the pretreatment period $(\mathrm{d}-7)$, the amount of PRL released at milking and the basal plasma PRL concentration were similar for the 2 treatment groups (Table $1)$. On d -6 , we determined basal plasma PRL concen- 


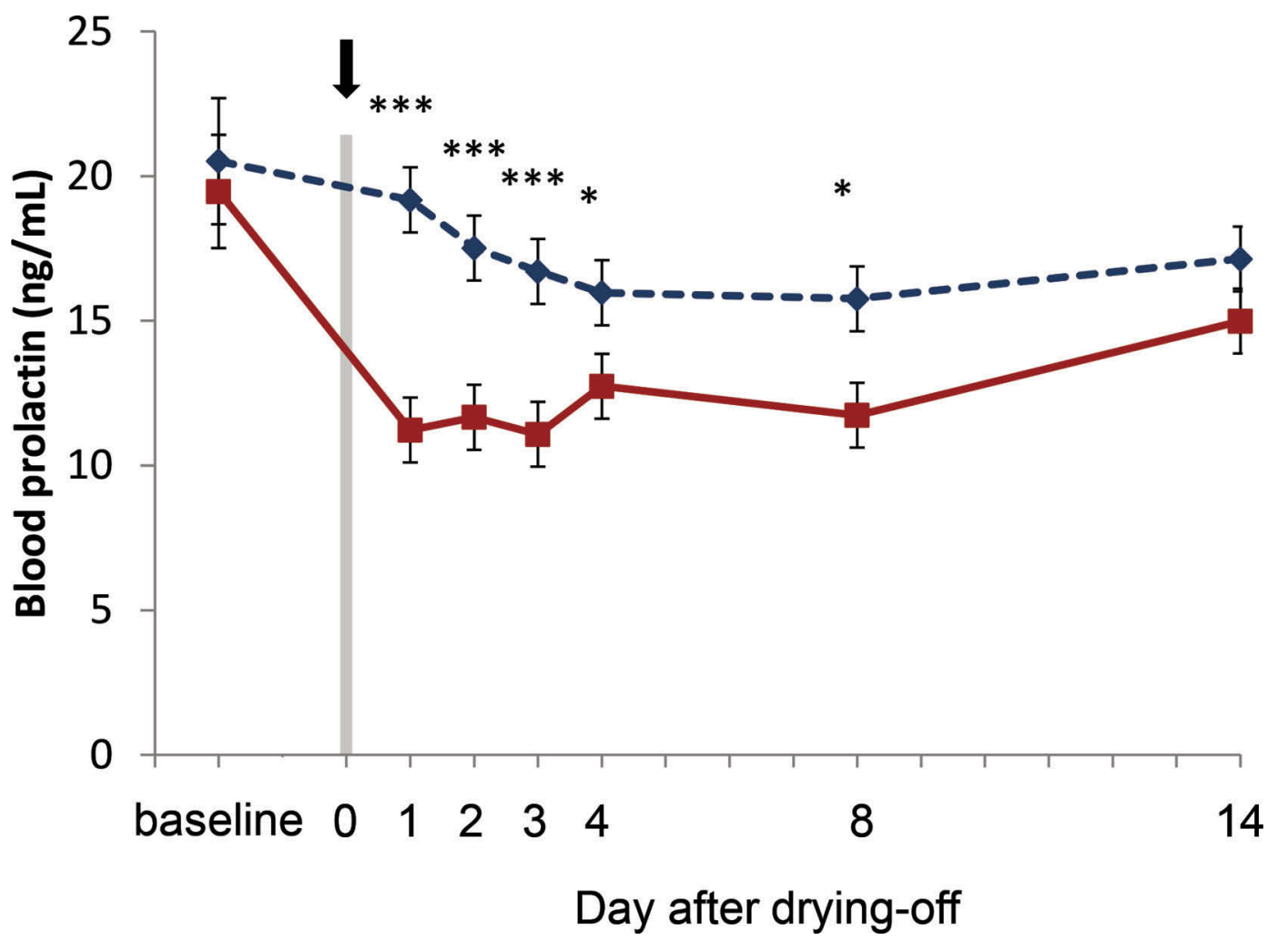

Figure 1. Prolactin concentration in the plasma collected before morning milking at d -6 (baseline) and during dry-off (d $1,2,3,4,8$, and 14 ) in dairy cows injected (arrow) with cabergoline $(5.6 \mathrm{mg}$, injected i.m.; $\mathrm{n}=7 ; \mathbf{\square}$ ) or the vehicle (control; $\mathrm{n}=7 ; \boldsymbol{*}$ ) at $\mathrm{d} 0$ of drying-off (gray bar). Data are presented as LSM \pm SEM $(* * * P<0.001 ; * P<0.05)$. Color version available online.

tration before milk sample collection. Before drying-off (d -6), basal plasma PRL concentration was similar for the 2 groups of animals $(P=0.80$, Figure 1$)$. The effect of day was significant, suggesting that plasma PRL concentrations decreased from drying-off onward in both groups $(P<0.001$, Figure 1$)$. However, we observed this decrease from the basal lactating level from d 1 of drying-off in the CAB group $(P<0.01)$, whereas the decrease occurred at $\mathrm{d} 2$ for the control group $(P<$ 0.05). Cabergoline treatment at dry-off decreased plasma PRL concentrations by $39 \%(P<0.001)$ compared to CRTL. The reduction of plasma PRL concentrations persisted following cabergoline treatment from d 1 to 8 of drying-off $(P<0.001)$.

\section{Effect of Drying-Off on Mammary Secretion Composition}

During the pretreatment period, lactose, fat, and protein contents in milk collected before milking were similar for the 2 groups of cows $(P=0.76$, Figure $2 ; P$ $=0.77$, Figure 3 ; and $P=0.37$, Table 2 , respectively).

In both groups, lactose content in mammary secretions decreased from drying-off onward $(P<0.0001$,
Figure 2) and fat content increased from drying-off onward $(P=0.04$, Figure 3$)$. In both groups, true protein content increased from d 2 of drying-off $(P<$ 0.001, Table 2). Similarly, the lactoferrin concentration in mammary secretions increased from d 4 to $\mathrm{d} 14$ in both groups, with a significant time effect $(P<0.0001$, Figure 4). In contrast, the concentration of $\alpha$-LA in mammary secretions decreased after drying-off $(P<$ 0.0001 , Table 2). Citrate concentration in mammary secretions increased during the first 3 days after dryingoff and then decreased from d 4 onward $(P<0.0001$, Table 2). The citrate:lactoferrin molar ratio decreased after drying-off $(P<0.0001$, Table 2$)$, whereas SCC increased after drying-off $(P<0.001)$.

\section{Effect of Cabergoline Treatment on Mammary Secretion Composition}

Over the entire trial period, we observed no significant effect of cabergoline on lactose content in mammary secretions $(P=0.22)$. However, the decline of lactose was accelerated in the cabergoline-treated group: lactose content in mammary secretions at $d 1$ 


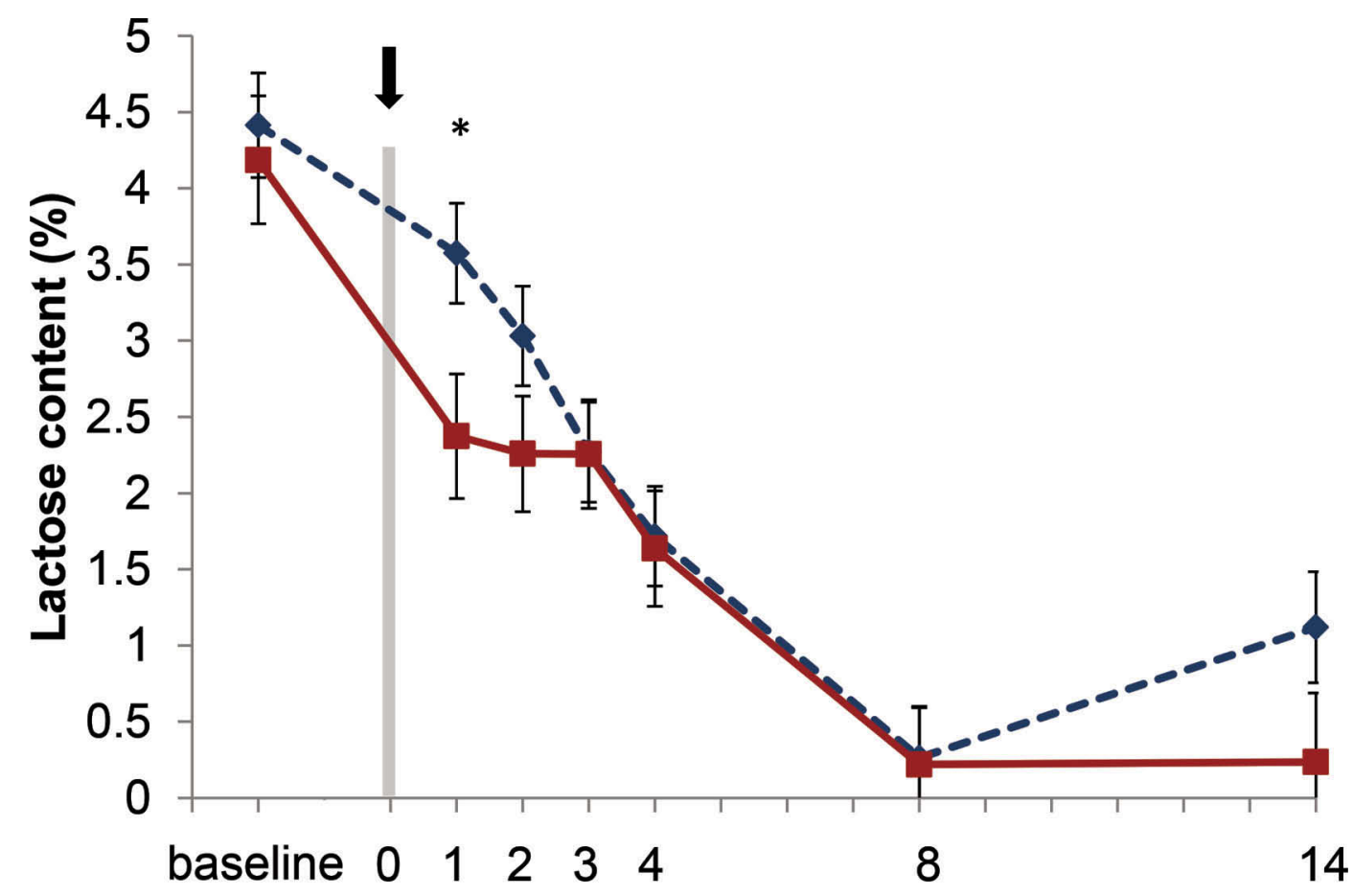

Day after drying-off

Figure 2. Lactose content in mammary secretions collected before morning milking at d -6 (baseline) and during drying-off (d $1,2,3,4,8$, and 14) in dairy cows injected (arrow) with cabergoline (5.6 mg, injected i.m.; $\mathrm{n}=7 ; \mathbf{\square}$ ) or the vehicle (control; $\mathrm{n}=7 ; \boldsymbol{\vee})$ at d 0 of drying-off (gray bar). Data are presented as $\operatorname{LSM} \pm \operatorname{SEM}\left({ }^{*} P<0.05\right)$. Color version available online.

was $34 \%$ lower in CAB cows than in CTRL cows $(P=$ 0.027, Figure 2).

The fat content of mammary secretions was not affected by treatment with cabergoline $(P=0.25)$, but fat content tended to be higher on $\mathrm{d} 3$ in the $\mathrm{CAB}$ group than in the CTRL $(P=0.08$, Figure 3$)$. Compared with fat content in milk during lactation $(\mathrm{d}-6)$, the increase occurred on $\mathrm{d} 3$ for the CAB group, whereas it occurred on d 4 in the CTRL (Figure 3).

Cabergoline did not have any effect on true protein content in mammary secretions $(P=0.28$, Table 2$)$. Similarly, we observed that cabergoline had no effect on $\alpha$-LA concentration in mammary secretions $(P=$ 0.53 , Table 2). In contrast, the lactoferrin concentration in mammary secretions during drying-off was $51 \%$ higher in the CAB group than in the CTRL group $(P$ $=0.05)$. Figure 4 shows that the lactoferrin concentrations tended to be higher on d 4 and d 14: on average, 11.4 and $26.9 \mathrm{mg} / \mathrm{mL}$ for $\mathrm{CAB}$ versus 3.8 and $19.8 \mathrm{mg} /$ $\mathrm{mL}$ for CTRL, respectively $(P=0.06$ and $P=0.09)$. Compared with lactation $(\mathrm{d}-6)$, the increase in lactoferrin concentration in mammary secretions during drying-off occurred on d 1 for $\mathrm{CAB}(P=0.05)$ and d 2 for CTRL $(P=0.04$, Figure 4$)$.
We did not observe any effect of cabergoline on citrate concentration $(P=0.85)$ or on the citrate:lactoferrin molar ratio $(P=0.20$, Table 2$)$ over the entire study period. However, the ratio was lower in $\mathrm{CAB}$ than in CTRL on d $1(P<0.01$, Table 2$)$.

Somatic cell count in milk collected before milking was similar for the 2 groups of cows $(P=0.82$, Figure $5)$. During drying-off, SCC was 1.4-fold higher in CAB cows than in CTRL cows $(P<0.01$, Figure 5). This effect was significant on d 1,2 , and $3(P<0.05)$, and we observed a trend toward higher SCC in CAB than in CTRL on d $4(P=0.07)$. However, we did not see a cabergoline effect on d 8 or 14 (Figure 5).

\section{DISCUSSION}

Dairy cattle require a dry period between successive lactations to ensure optimal milk production (Capuco and Akers, 1999; Kunh et al., 2006; Watters et al., 2008). This dry period is mainly marked by cessation of milking, which induces morphological and functional changes in the mammary gland (Holst et al., 1987; Oliver and Sordillo, 1989; Capuco et al., 1997). Cessation of milking is also associated with a concomitant pause 
of PRL release into blood that usually occurs because of teat stimulation during milking (Koprowski and Tucker, 1973). Recent evidence suggests that PRL is galactopoietic in dairy ruminants because it maintains both the number and the differentiation of mammary epithelial cells during lactation (Lacasse et al., 2016). Thus, PRL inhibition could be used to reduce milk production at drying-off and to accelerate the rate of mammary involution after cessation of milking. In this study, we tested a new strategy to facilitate the drying-off of cows by injecting cabergoline, a PRLrelease inhibitor, at the end of lactation. Cabergoline is a dopamine agonist that inhibits PRL secretion by lactotroph cells as a consequence of its binding to D2 dopamine receptors (Eguchi et al., 1995). In our study, cessation of milk removal induced a decrease in plasma PRL concentrations in both groups of cows. As expected, a single injection of cabergoline $(5.6 \mathrm{mg} / \mathrm{cow})$ induced an even greater decrease in PRL concentration following cessation of milk removal in comparison with CTRL cows. One single injection on the day of dry-off was able to reduce PRL concentration not only on the first day following the injection, but also through the first $8 \mathrm{~d}$ of the dry period. In a previous experiment, with more cows, the same dose of cabergoline administered at the cessation of lactation effectively reduced plasma PRL concentrations through $15 \mathrm{~d}$ after dryingoff, with a half-life of cabergoline of $20 \mathrm{~h}$ (EMA, 2015). This is consistent with the known long-lasting effect of cabergoline on PRL inhibition in humans (Pontiroli et al., 1987). Indeed, the reported half-life of cabergoline in humans is $65 \mathrm{~h}$, whereas another dopamine agonist, quinagolide, has a half-life of only $22 \mathrm{~h}$ (Crosignani, 2006). Interestingly, previous studies using quinagolide in cows in an attempt to suppress lactation were also effective in reducing plasma PRL concentrations (Ollier et al., 2013). However, the ability of quinagolide to effectively block PRL secretion required multiple daily treatments to achieve biological activity similar to that of a single dose of cabergoline. Although the half-life of quinagolide in bovines is not established, treatment disparities between cabergoline and quinagolide needed to block PRL secretion effectively may be explained by differences in their half-life in dairy cows. Results from the present study showed that PRL production by the pituitary gland was effectively reduced for $8 \mathrm{~d}$ during

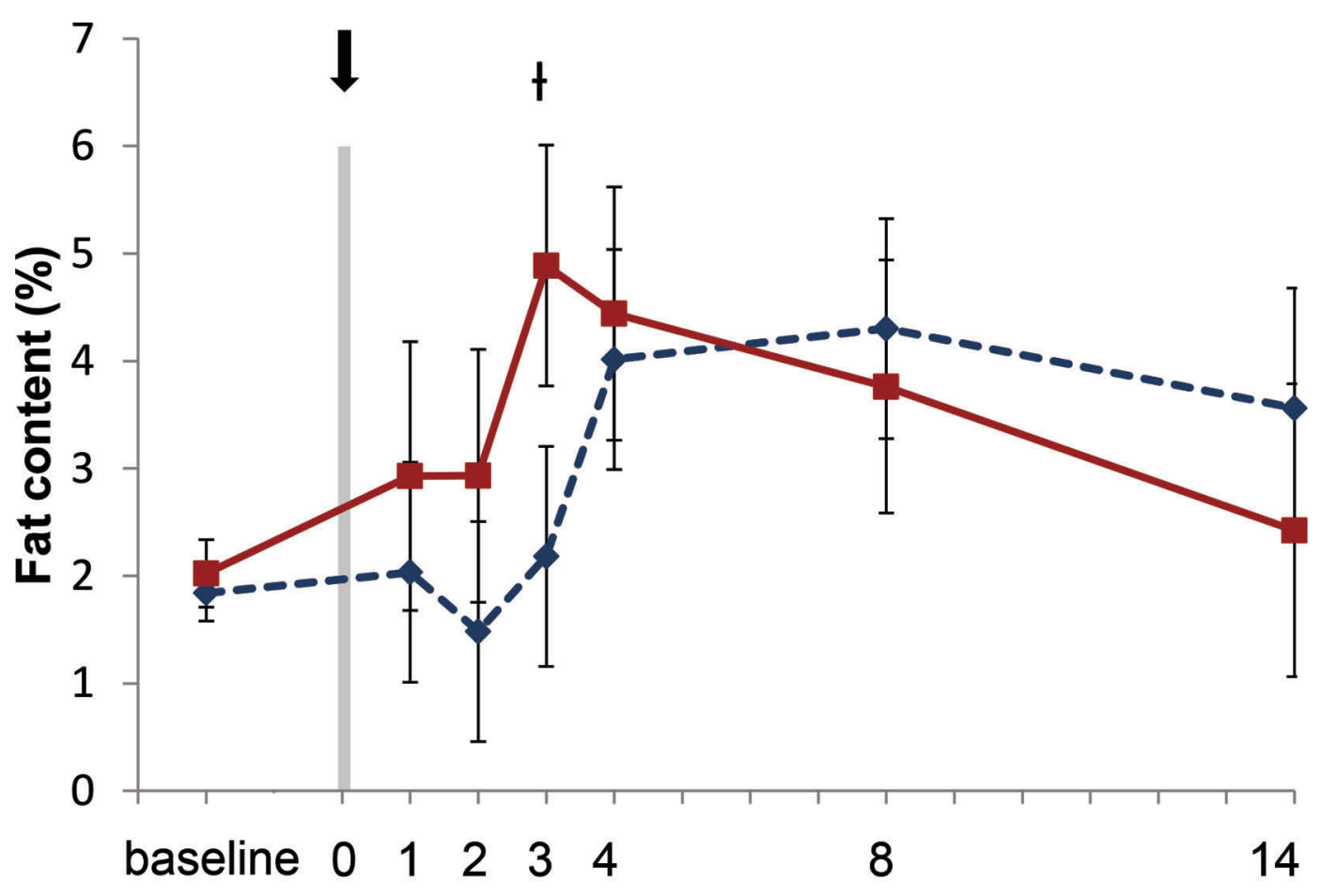

Day after drying-off

Figure 3. Fat content in mammary secretions collected before morning milking at d -6 (baseline) and during drying-off (d 1, 2, 3, 4, 8 , and 14) in dairy cows injected (arrow) with cabergoline $(5.6 \mathrm{mg}$, injected i.m.; $\mathrm{n}=7 ; \mathbf{Q}$ ) or the vehicle (control; $\mathrm{n}=7 ; \boldsymbol{*}$ ) at $\mathrm{d} 0$ of drying-off (gray bar). Data are presented as LSM \pm SEM $(\dagger P<0.10)$. Color version available online. 
drying-off with only a single dose of cabergoline; this may suggest practical applications in typical commercial dairy herd management schemes.

The analysis of changes in mammary secretion composition during the first $14 \mathrm{~d}$ of drying-off was used to provide information about the rate and speed of mammary involution after cabergoline injection. Rapid and gradual changes in mammary secretion volume and composition, respectively, at the time of dry-off occur because of an engorgement of alveolar compartments with milk constituents and inhibition of milk synthesis (Wheelock et al., 1967; Hurley, 1989; Oliver and Sordillo, 1989). Changes in lactose content of mammary secretions during the dry period are often used as a marker for involution because lactose is a major constituent of milk and essential in regulating mammary fluid volume (Jenness and Holt, 1987). We observed an abrupt decrease in lactose content in mammary secretions during early involution, which is consistent with the findings of previous studies (Hurley, 1989; Oliver and Sordillo, 1989). Lower lactose concentrations were observed in the CAB group within the first day following administration than in the CTRL group. Lactose synthesis is known to be regulated by PRL following the induction of glucose afflux to mammary epithelial cells (Riskin et al., 2008) and stimulating gene expression of $\alpha-L A$, which is a co-enzyme responsible for the last step of lactose synthesis (Jagoda and Rillema, 1991). Cabergoline did not affect $\alpha$-LA concentration in mammary secretions, but the decrease in lactose content may be a consequence of changes in glucose availability for lactose synthesis. Previous studies support the concept that blocking PRL availability is related to milk lactose by using an alternative D2 dopamine agonist, quinagolide. Indeed, treatment of dairy cows with quinagolide effectively lowered milk lactose content and reduced milk yield during both mid and late lactation (Lacasse et al., 2011; Ollier et al., 2013; Lollivier et al., 2015). The more rapid decrease in lactose content observed in this study suggests more efficient cessation of milk synthesis activity by mammary epithelial cells in $\mathrm{CAB}$ cows than in CTRL cows and is consistent with the findings of previous studies using another PRL release inhibitor (Boutinaud et al., 2012).

During the early dry period, we observed a progressive increase in fat content that may reflect a transient accumulation of milk fat in the alveolar compartment and a problem with the evacuation of fat from the alveolar compartment, as reported in previous studies (Sordillo and Nickerson, 1988). The increase in milk fat content following dry-off occurred earlier for the CAB group than for the CTRL group, suggesting that in addition to reducing lactose concentrations, cabergoline accelerated the accumulation of fat during the early 


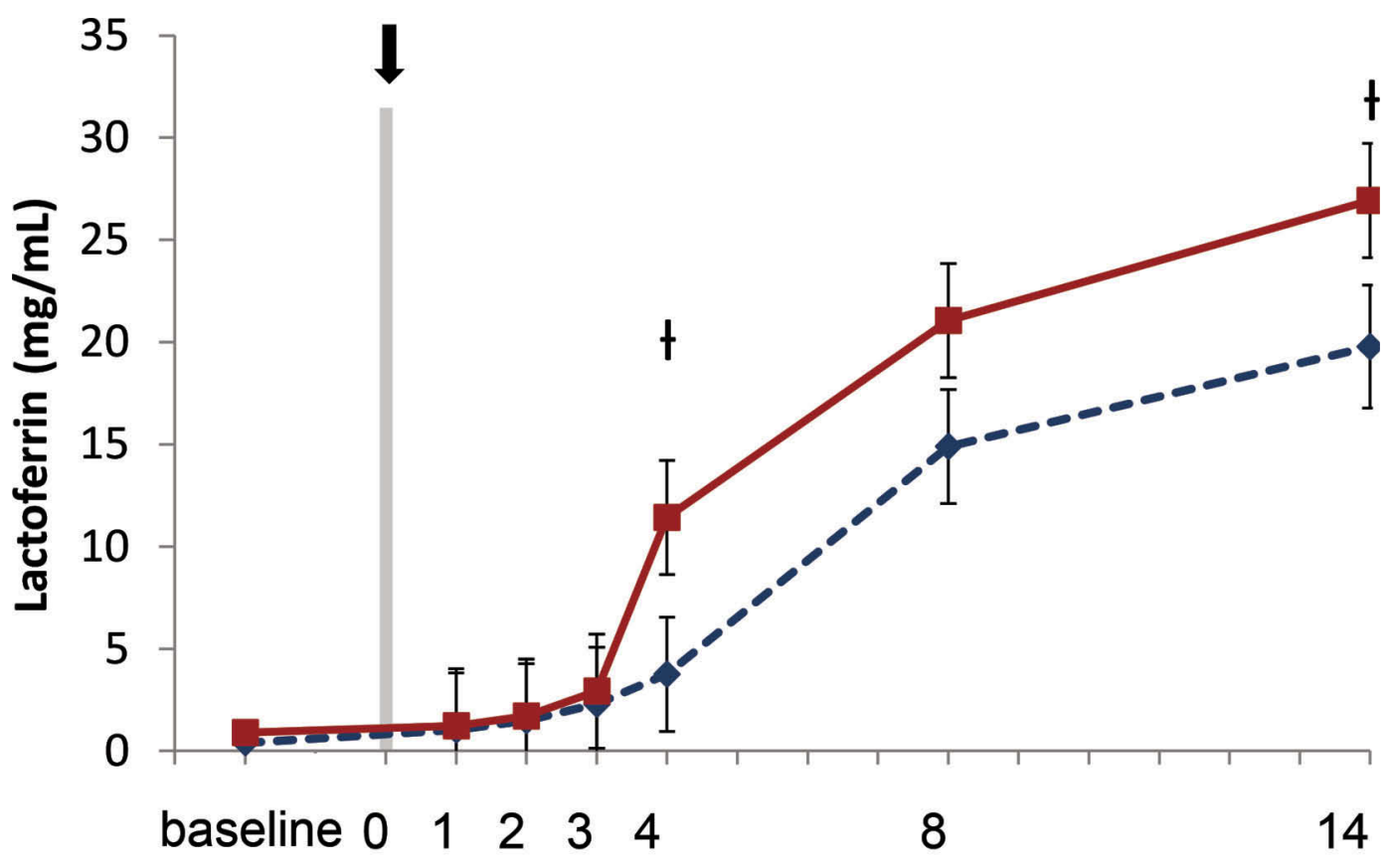

Day after drying-off

Figure 4. Lactoferrin concentration in mammary secretions collected before morning milking at d -6 (baseline) and during drying-off (d 1 , $2,3,4,8$, and 14) in dairy cows injected (arrow) with cabergoline ( $5.6 \mathrm{mg}$, injected i.m.; $\mathrm{n}=7 ; \mathbf{\square})$ or the vehicle $($ control; $\mathrm{n}=7 ;-)$ at $\mathrm{d} 0$ of drying-off (gray bar). Data are presented as LSM \pm SEM $(\dagger P<0.10)$. Cabergoline increased lactoferrin concentration $(P=0.05)$. Color version available online.

days of the dry period. In previous studies, increased fat in mammary secretions was associated with diminished synthetic and secretory activity in mammary epithelial cells and the delayed elimination of accumulated fat droplets (Sordillo and Nickerson, 1988; Oliver and Sordillo, 1989). Increased fat content may also reflect a concentration effect that is due to reduced fluid volume in the mammary gland. Because lactose is a major osmotic component of milk, dramatic decreases in lactose concentration are accompanied by concomitant reductions in milk volume (Jenness and Holt, 1987). Thus, the more pronounced decrease in lactose concentration in the CAB group may have contributed to the higher fat content of mammary secretions as a result of more rapid reductions in fluid accumulation during the first days of the dry period. This assertion is supported by a recent study that reported less udder engorgement and milk leakage during the dry period in cows treated with cabergoline than in untreated control cows (Bach et al., 2015).

During the early dry period, the cow is highly susceptible to new IMI (Dingwell et al., 2003). Although milk is not being removed after dry-off, the mammary gland temporarily continues to synthesize milk, which is accumulated in the udder and causes an increase in mammary pressure and possible milk leakage from the teats (Klaas et al., 2005). Increased patency of the teat end and residual milk can facilitate microbial entry into and growth within the mammary gland during the early dry period. Thus, the ability to reduce fluid accumulation and milk leakage at the time of dry-off is one way that a PRL release inhibitor such as cabergoline may enhance the natural defense mechanisms of the mammary gland. Once bacteria breach the teat-end barrier, however, other cellular and soluble immune defenses play a major role in the establishment of new IMI (Aitken et al., 2011). Lactoferrin is an iron ligand that has numerous antimicrobial and immunotropic properties (El-Loly and Mahfouz, 2011). In the mammary gland, the antimicrobial efficacy of lactoferrin is negatively correlated with citrate content in the milk. Indeed, the bacteriostatic activity of lactoferrin in mammary secretions is more effective as the citrate:lactoferrin molar ratio decreases (Kutila et al., 2003). The lactoferrin and citrate concentrations in mammary secretions and the citrate:lactoferrin molar ratio are also markers of mammary gland involution (Kutila et al., 2003). In our study, in both groups of cows, lactoferrin concentration increased while citrate concentration and citrate:lactoferrin molar ratio progressively decreased 
during drying-off. Cabergoline induced globally higher lactoferrin concentrations in mammary secretions. This effect of cabergoline on lactoferrin may have resulted from increased synthesis by mammary epithelial cells or lactoferrin release by infiltrating somatic cells (Pecorini et al., 2009). In the present study, we did not observe any effect of cabergoline on citrate concentration. However, the citrate:lactoferrin molar ratio was lower at $\mathrm{d} 1$ of drying-off in CAB than in CTRL. The higher level of lactoferrin and the lower citrate:lactoferrin molar ratio suggest a more robust innate immune capacity in $\mathrm{CAB}$ cows than in CTRL cows.

Cessation of milking induces mammary gland involution, which is also characterized by leukocyte infiltration into the mammary tissue (Oliver and Sordillo, 1989) and massive increases in SCC content in mammary secretions (Jensen and Eberhart, 1981). In both groups of cows, SCC increased in the early phase of drying-off. Infiltration of leukocytes into mammary tissues is thought to play a dominant role in mammary gland involution (Atabai et al., 2007). In our study, CAB cows had higher SCC levels in mammary secretions than CTRL cows did, especially during the first $3 \mathrm{~d}$ after the cessation of milking. This effect is in accordance with the more rapid increase in SCC observed previously with quinagolide treatment at drying-off (Ollier et al., 2013). Atabai et al. (2007) hypothesized that leukocyte infiltration into mammary tissue played a role in the remodeling of the tissue. Nickerson (1989) and Atabai et al. (2007) suggested that the SCC in mammary secretions participate in the removal of apoptotic cells in mammary tissue and in the degradation of the milk engorged in the alveolar lumen during involution. Macrophages are the predominant leukocyte type in mammary secretions during early involution, and their phagocytic properties can also enhance the antibacterial defense against mastitis-causing pathogens (Aitken et al., 2011). Thus, the higher SCC content in mammary secretions from the CAB group may not only facilitate mammary tissue remodeling processes, but also enhance local mammary gland immune mechanisms against mastitis-causing pathogens during the early dry period.

\section{CONCLUSIONS}

Using cabergoline, a dopamine agonist, to inhibit PRL release is an effective strategy for reducing the synthesis and secretion of milk during the early dry period. The major findings from this study are that a

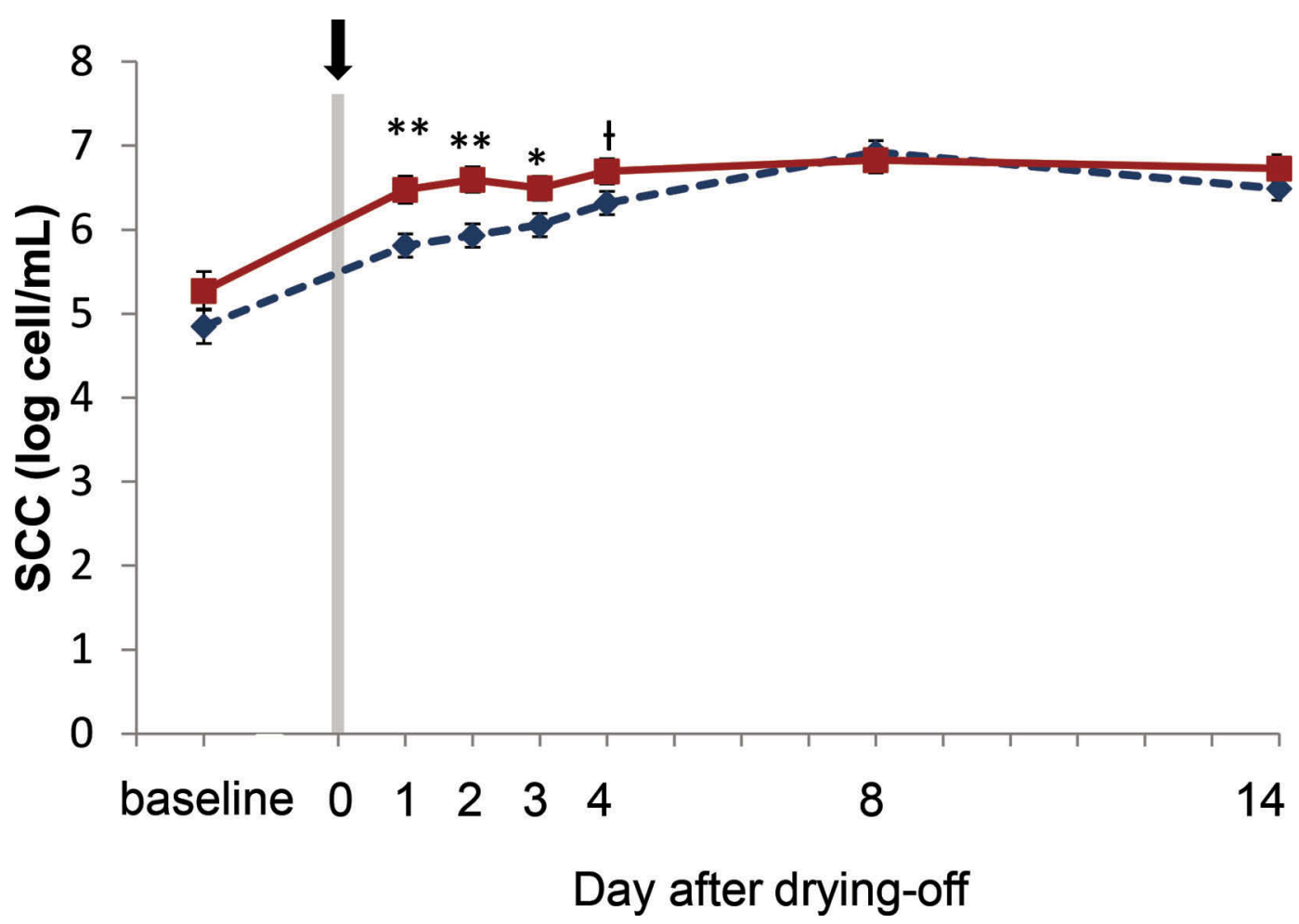

Figure 5. Somatic cell count in mammary secretions collected before morning milking at d -6 (baseline) and during drying-off (d 1, 2, 3, 4,

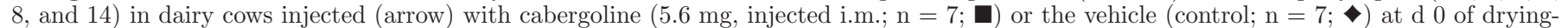
off (gray bar). Data are presented as LSM \pm SEM $\left(* * P<0.01 ;{ }^{*} P<0.05 ; \dagger P<0.10\right)$. Cabergoline increased SCC $(P<0.01)$. Color version available online. 
single injection of cabergoline administered at the time of dry-off significantly decreased the PRL concentration for up to $8 \mathrm{~d}$ after drying-off. Changes in mammary secretion composition during the early dry period suggest that cabergoline effectively accelerated the involution process by reducing the secretory activity of mammary epithelial cells. Moreover, cabergoline treatment increased the presence of important mammary gland defense mechanisms earlier in the involution process in comparison with control cows. A better understanding of how cabergoline might contribute to mammary tissue remodeling would provide more insight into the involution process. Ultimately, the ability to accelerate involution could facilitate dairy management and improve the health and well-being of dairy cows at the time of dry-off.

\section{ACKNOWLEDGMENTS}

The authors thank the team of the experimental farm (IEPL, INRA, Le Rheu, France) for taking care of the cows and for their assistance with milk, plasma, and mammary secretion sampling. We are also grateful to S. Marion, L. Finot, S. Wiart, A. Gillard, A. Emo, C. Mustière, P. Potton, and T. Le Mouël (INRA, SaintGilles, France) for their technical help and J. Bertet (Ceva Santé Animale, Libourne, France) for assistance with monitoring the data. The authors are grateful to Ceva Santé Animale (Libourne, France) for providing partial funding to conduct this study.

\section{REFERENCES}

Aitken, S. L., C. M. Corl, and L. M. Sordillo. 2011. Immunopathology of mastitis: Insights into disease recognition and resolution. J. Mammary Gland Biol. Neoplasia 16:291-304.

Atabai, K., D. Sheppard, and Z. Werb. 2007. Roles of the innate immune system in mammary gland remodeling during involution. J. Mammary Gland Biol. Neoplasia 12:37-45.

Bach, A., A. De-Prado, and A. Aris. 2015. Short communication: The effects of cabergoline administration at dry-off of lactating cows on udder engorgement, milk leakages, and lying behavior. J. Dairy Sci. 98:7097-7101. 10.3168/jds.2015-9751.

Boutinaud, M., V. Lollivier, L. Finot, R. M. Bruckmaier, and P. Lacasse. 2012. Mammary cell activity and turnover in dairy cows treated with the prolactin-release inhibitor quinagolide and milked once daily. J. Dairy Sci. 95:177-187.

Bushe, T., and S. P. Oliver. 1987. Natural protective factors in bovine mammary secretions following different methods of milk cessation. J. Dairy Sci. 70:696-704.

Capuco, A. V., and R. M. Akers. 1999. Mammary involution in dairy animals. J. Mammary Gland Biol. Neoplasia 4:137-144.

Capuco, A. V., R. M. Akers, and J. J. Smith. 1997. Mammary growth in Holstein cows during the dry period: Quantification of nucleic acids and histology. J. Dairy Sci. 80:477-487.

Capuco, A. V., S. E. Ellis, S. A. Hale, E. Long, R. A. Erdman, X. Zhao, and M. J. Paape. 2003. Lactation persistency: Insights from mammary cell proliferation studies. J. Anim. Sci. 81(Suppl. 3):18-31.

Collier, R. J., E. L. Annen-Dawson, and A. Pezeshki. 2012. Effects of continuous lactation and short dry periods on mam- mary function and animal health. Animal 6:403-414. 10.1017/ S1751731111002461.

Crosignani, P. G. 2006. Current treatment issues in female hyperprolactinaemia. Eur. J. Obstet. Gynecol. Reprod. Biol. 125:152-164.

de Groot, A. N., P. W. van Dongen, T. B. Vree, Y. A. Hekster, and J. van Roosmalen. 1998. Ergot alkaloids. Current status and review of clinical pharmacology and therapeutic use compared with other oxytocics in obstetrics and gynaecology. Drugs 56:523-535.

Dingwell, R. T., D. F. Kelton, and K. E. Leslie. 2003. Management of the dry cow in control of peripartum disease and mastitis. Vet. Clin. North Am. Food Anim. Pract. 19:235-265.

Eguchi, K., K. Kawamoto, T. Uozumi, A. Ito, K. Arita, and K. Kurisu. 1995. Effect of cabergoline, a dopamine agonist, on estrogen-induced rat pituitary tumors: In vitro culture studies. Endocr. J. $42: 413-420$.

El-Loly, M. M., and M. B. Mahfouz. 2011. Lactoferrin in relation to biological functions and applications: A review. Int. J. Dairy Sci. 6:79-111.

European Medicines Agency. 2015. Velactis $1.12 \mathrm{mg} / \mathrm{ml}$ Solution for Injection for Cattle. Summary of Product Characteristics (SPC). European Medicines Agency, London, UK.

Gobello, C. 2006. Dopamine agonists, anti-progestins, anti-androgens, long-term-release $\mathrm{GnRH}$ agonists and anti-estrogens in canine reproduction: A review. Theriogenology 66:1560-1567.

Holst, B. D., W. L. Hurley, and D. R. Nelson. 1987. Involution of the bovine mammary gland: Histological and ultrastructural changes. J. Dairy Sci. 70:935-944.

Hurley, W. L. 1989. Mammary gland function during involution. J. Dairy Sci. 72:1637-1646.

Ingram, C. D., R. J. Bicknell, and W. T. Mason. 1986. Intracellular recordings from bovine anterior pituitary cells: Modulation of spontaneous activity by regulators of prolactin secretion. Endocrinology 119:2508-2518.

Jagoda, C. A., and J. A. Rillema. 1991. Temporal effect of prolactin on the activities of lactose synthetase, alpha-lactalbumin, and galactosyl transferase in mouse mammary-gland explants. Proc. Soc. Exp. Biol. Med. 197:431-434.

Jenness, R., and C. Holt. 1987. Casein and lactose concentrations in milk of 31 species are negatively correlated. Experientia 43:10151018.

Jensen, D. L., and R. J. Eberhart. 1981. Total and differential cell counts in secretions of the nonlactating bovine mammary gland. Am. J. Vet. Res. 42:743-747.

Klaas, I. C., C. Enevoldsen, A. K. Ersbøll, and U. Tölle. 2005. Cowrelated risk factors for milk leakage. J. Dairy Sci. 88:128-136.

Kollmann, M. T., M. Locher, F. Hirche, K. Eder, H. H. D. Meyer, and R. M. Bruckmaier. 2008. Effects of tryptophan supplementation on plasma tryptophan and related hormone levels in heifers and dairy cows. Domest. Anim. Endocrinol. 34:14-24.

Koprowski, J. A., and H. A. Tucker. 1973. Serum prolactin during various physiological states and its relationship to milk production in the bovine. Endocrinology 92:1480-1487.

Kuhn, M. T., J. L. Hutchison, and H. D. Norman. 2006. Dry period length to maximize production across adjacent lactations and lifetime production. J. Dairy Sci. 89:1713-1722.

Kutila, T., S. Pyörälä, L. Kaartinen, R. Isomäki, K. Vahtola, L. Myllykoski, and H. Saloniemi. 2003. Lactoferrin and citrate concentrations at drying-off and during early mammary involution of dairy cows. J. Vet. Med. A Physiol. Pathol. Clin. Med. 50:350-353.

Lacasse, P., V. Lollivier, R. M. Bruckmaier, Y. R. Boisclair, G. F. Wagner, and M. Boutinaud. 2011. Effect of the prolactin-release inhibitor quinagolide on lactating dairy cows. J. Dairy Sci. 94:1302-1309.

Lacasse, P., S. Ollier, V. Lollivier, and M. Boutinaud. 2016. New insights into the importance of prolactin in dairy ruminants. J. Dairy Sci. 99:864-874.

Lollivier, V., P. Lacasse, J. Angulo Arizala, P. Lamberton, S. Wiart, J. Portanguen, and M. Boutinaud. 2015. In vivo inhibition followed by exogenous supplementation demonstrates galactopoietic effects of prolactin on mammary tissue and milk production in dairy cows. J. Dairy Sci. 10.3168/jds.2015-9853. PubMed 
Nickerson, S. C. 1989. Immunological aspects of mammary involution. J. Dairy Sci. 72:1665-1678.

O'Driscoll, K., D. Gleeson, B. O'Brien, and L. Boyle. 2011. Does omission of a regular milking event affect cow comfort? Livest. Sci. 138:132-143.

Oliver, S. P., and L. M. Sordillo. 1989. Approaches to the manipulation of mammary involution. J. Dairy Sci. 72:1647-1664.

Ollier, S., X. Zhao, and P. Lacasse. 2013. Effect of prolactin-release inhibition on milk production and mammary gland involution at drying-off in cows. J. Dairy Sci. 96:335-343.

Pecorini, C., S. Delpal, S. Truchet, F. Le Provost, A. Baldi, and M. Ollivier-Bousquet. 2009. Lactoferrin at basal side of mouse mammary epithelium derives in part from stroma cells. Cell Tissue Res. 338:241-255. http://dx.doi.org/10.1007/s00441-009-0873-z.

Pontiroli, A. E., G. C. Viberti, R. Mangili, L. Cammelli, and A. Dubini. 1987. Selective and extremely long inhibition of prolactin release in man by 1-ethyl-3-(3'-dimethylaminopropyl)-3-(6'allylergoline-8'-beta-carbonyl)-urea-diphosphate (FCE 21336). Br. J. Clin. Pharmacol. 23:433-438.

Rajala-Schultz, P. J., J. S. Hogan, and K. L. Smith. 2005. Short communication: Association between milk yield at dry-off and probability of intramammary infections at calving. J. Dairy Sci. $88: 577-579$.

Riskin, A., V. H. Nannegari, and Y. Mond. 2008. Acute effectors of GLUT1 glucose transporter subcellular targeting in CIT3 mouse mammary epithelial cells. Pediatr. Res. 63:56-61.
Silanikove, N. 2014. Natural and abrupt involution of the mammary gland affects differently the metabolic and health consequences of weaning. Life Sci. 102:10-15. http://dx.doi.org/10.1016/j. lfs.2014.02.034.

Sordillo, L. M., and S. C. Nickerson. 1988. Morphologic changes in the bovine mammary gland during involution and lactogenesis. Am. J. Vet. Res. 49:1112-1120.

Stefanon, B., M. Colitti, G. Gabai, C. H. Knight, and C. J. Wilde. 2002. Mammary apoptosis and lactation persistency in dairy animals. J. Dairy Res. 69:37-52.

Watters, R. D., J. N. Guenther, A. E. Brickner, R. R. Rastani, P. M. Crump, P. W. Clark, and R. R. Grummer. 2008. Effects of dry period length on milk production and health of dairy cattle. J. Dairy Sci. 91:2595-2603. http://dx.doi.org/http://dx.doi.org/10.3168/ jds.2007-0615.

Wheelock, J. V., A. Smith, F. H. Dodd, and R. L. J. Lyster. 1967. Changes in the quantity and composition of mammary gland secretion in the dry period between lactations: I. The beginning of the dry period. J. Dairy Res. 34:1-12.

Zobel, G., D. M. Weary, K. E. Leslie, and M. A. von Keyserlingk. 2015. Invited review: Cessation of lactation: Effects on animal welfare. J Dairy Sci. 98:8263-8277. http://dx.doi.org/10.3168/jds.2015-9617. 